\title{
ANALISIS KETERSEDIAAN AIR UNTUK MENDUKUNG KETAHANAN PANGAN DI KABUPATEN MALAKA, NUSA TENGGARA TIMUR
}

\author{
Yulianingsani ${ }^{* 1}$, Haryono Putro ${ }^{2}$ \\ 1Mahasiswa, Program Magister, Jurusan Manajemen Rekayasa Infrastruktur, Fakultas \\ Teknik Sipil dan Perencanaan, Universitas Gunadarma \\ 2Dosen, Jurusan Manajemen Rekayasa Infrastruktur, Fakultas Teknik Sipil dan \\ Perencanaan, Universitas Gunadarma \\ Korespondensi: yulianingsani23@gmail.com
}

\begin{abstract}
The growth of population causes growth in food needs. It cause availability of agricultural land getting smaller. The purpose of this study is to know the carrying capacity of agricultural land and analize water availability to support food security in Malaka. Malaka is an export-oriented food storage area in the border region (LPBE-WP). Based on the result of analisys, carrying capacity of agricultural land in Malaka on 2020-2024 is $\sigma<1$. It means this region cannot afford food self-sufficiency, population beyond the limits of optimal (over populated). To achieve food self-sufficiency requires 12.516 hectares area of agricultural land. Based on water surplus graphics, the availability of water building infrastructure in Malaka cannot fulfill agricultural water needs. The volume of storage needed to fulfill agricultural water need is 86,201 million cubic meters.
\end{abstract}

Keywords : carrying capacity of agricultural land, food security, water needs

\section{PENDAHULUAN}

Persoalan pangan ke depan semakin komplek yang menjadi isu strategis dan perhatian semua negara di dunia, termasuk Indonesia. Hal ini terutama terkait dengan masalah sumber daya lahan, air, tenaga kerja dan dampak perubahan iklim. Berdasarkan kajian yang dirilis The Economist Intelligence Unit (EIU), Global Food Security Index (GFSI) atau Indeks Ketahanan Pangan, tahun 2018 Indonesia berada peringkat 65 dari 113 negara dengan score 54,8 [1]. Indeks ini terdiri dari empat kategori yaitu keterjangkauan (affordability), ketersediaan (availability), kualitas dan keamanan (quality and safety) dan sumber daya alam dan ketahanan (natural resources and resilience).

Indonesia memiliki potensi yang mampu berkontribusi mengatasi masalah pangan dunia, antara lain melalui pembangunan lumbung pangan di berbagai wilayah, termasuk wilayah perbatasan. Kementerian Pertanian telah mencanangkan "Indonesia Menuju Lumbung
Pangan Dunia 2045 (LPD-45) dengan menetapkan program Lumbung Pangan Berorientasi Ekspor di Wilayah Perbatasan (LPBE-WP) sebagai program aksi prioritas dalam mewujudkannya [2]. Pada tahap awal, pengembangan LPBE-WP difokuskan pada 11 kabupaten di lima provinsi. Salah satu kabupaten yang termasuk dalam program LPBE-WP yaitu Kabupaten Malaka, Nusa Tenggara Timur. Kabupaten Malaka berbatasan langsung dengan Timor Leste.

Produksi pertanian dipengaruhi pasokan air, kekeringan dan banjir merupakan ancaman terus menerus bagi sektor pertanian akibat anomali dan ketidakpastian iklim serta degradasi lahan yang semakin luas. Dalam rangka mendukung ketahanan pangan diperlukan ketersediaan air yang cukup untuk tetap menjaga produktivitas pertanian. Berdasarkan hal tersebut, maka diperlukan analisis ketersediaan air di Kabupaten Malaka, agar ketersediaan air di kabupaten tersebut dapat mendukung program LPBE-WP. Selain 
itu diperlukan pula analisis mengenai daya dukung lahan pertanian karena pertumbuhan penduduk yang semakin besar akan menyebabkan ketersediaan lahan pertanian menjadi semakin kecil.

\section{TINJAUAN PUSTAKA}

\subsection{Ketahanan Pangan}

UU No. 18 tahun 2012 tentang pangan menjelaskan bahwa ketahanan pangan adalah kondisi terpenuhinya pangan bagi negara sampai dengan perseorangan, yang tercermin dari tersedianya pangan yang cukup, baik jumlah maupun mutunya, aman, beragam, bergizi, merata, dan terjangkau serta tidak bertentangan dengan agama, keyakinan, dan budaya masyarakat, untuk dapat hidup sehat, aktif, dan produktif secara berkelanjutan [3].

Tiga pilar dalam ketahanan pangan yang terdapat dalam definisi tersebut adalah ketersediaan (availability), keterjangkauan (accessibility) baik secara fisik maupun ekonomi, dan stabilitas (stability) yang harus tersedia dan terjangkau setiap saat dan setiap tempat [4]. Apabila ketiga pilar ketahanan pangan terpenuhi, maka masyarakat atau rumah tangga tersebut mampu memenuhi ketahanan pangannya masing-masing.

\subsection{Proyeksi Penduduk}

Ada beberapa cara untuk memproyeksikan jumlah penduduk masa yang akan datang diantaranya menggunakan metode matematik. Metode matematik sering disebut juga dengan metode tingkat pertumbuhan penduduk (growth rates). Proyeksi berdasarkan tingkat pertumbuhan penduduk mengasumsikan pertumbuhan yang konstan, baik untuk model aritmatika, geometrik, atau eksponensial untuk mengestimasi jumlah penduduk [5]. Perhitungan proyeksi penduduk dilakukan berdasarkan Buku Pedoman Perhitungan Proyeksi Penduduk dan Angkatan Kerja yang diterbitkan oleh BPS, 2010. Pemilihan metode paling tepat yang akan digunakan dalam penelitian, diperlukan perhitungan faktor korelasi dan standar deviasi. Metode proyeksi yang dipilih adalah metode dengan nilai standar deviasi terendah dan koefisien korelasi paling tinggi.

Metode Aritmatika:

$\mathrm{P}_{\mathrm{t}}=\mathrm{P}_{0}(1+\mathrm{rt})$ dengan $\mathrm{r}=\frac{1}{\mathrm{t}}\left(\frac{\mathrm{P}_{\mathrm{t}}}{\mathrm{P}_{0}}-1\right)$
Metode Geometrik

$\mathrm{P}_{\mathrm{t}}=\mathrm{P}_{0}(1+\mathrm{r})^{t}$ dengan $\mathrm{r}=\left(\frac{\mathrm{P}_{\mathrm{t}}}{\mathrm{P}_{0}}\right)^{\frac{1}{\mathrm{t}}}-1$

Metode Eksponensial

$P_{t}=P_{0} e^{r t}$ dengan $r=-\frac{1}{t} \ln \left(\frac{P_{t}}{P_{0}}\right)$

dimana:

$\mathrm{Pt}=$ jumlah penduduk pada tahun $\mathrm{t}$

$\mathrm{P0}=$ jumlah penduduk pada tahun dasar

$\mathrm{r} \quad=$ laju pertumbuhan penduduk

$\mathrm{t}=$ periode waktu antara tahun dasar dan tahun $\mathrm{t}$ (dalam tahun)

\subsection{Daya Dukung dan Kebutuhan Lahan}

Analisis yang digunakan dalam menentukan tingkat daya dukung lahan pertanian digunakan rumus dari konsep gabungan atas teori Odum, Christeiler, Ebenezer Howard dan Issard dalam Soehardjo dan Tukiran (1990) dalam Kuncoro, (2017) yaitu [6]:

$\sigma=\frac{\mathrm{X}}{\mathrm{K}}$

$\mathrm{X}=\frac{\text { Luas Panen (Ha) }}{\text { Jumlah Penduduk (jiwa) }}$

$\mathrm{K}=\frac{\text { Kebutuhan Fisik Minimum (KFM) }}{\text { Produksi Tanaman Pangan (Ha/Thn) }}$

dimana:

$\sigma=$ tingkat daya dukung lahan pertanian (DDL)

$\mathrm{X}=$ luas panen tanaman pangan per kapita

$\mathrm{K}$ = luas lahan untuk swasembada pangan

Kriteria nilai $\sigma$ yaitu sebagai berikut:

a. $\sigma>1$, berarti wilayah tersebut mampu swasembada pangan dalam arti jumlah penduduk berada di bawah jumlah penduduk optimal.

b. $\sigma<1$, berarti wilayah tersebut tidak mampu swasembada pangan dalam arti jumlah penduduknya telah melampaui jumlah penduduk optimal.

c. $\sigma=1$, berarti wilayah tersebut memiliki daya dukung yang optimal.

Berdasarkan rumus di atas maka, didapatkan rumus untuk menentukan kebutuhan lahan pertanian yaitu:

$\mathrm{KLPR}=\frac{\frac{\mathrm{KFM}}{\mathrm{Pr}} \times \text { Hasil Proyeksi Penduduk }}{\text { Angka konversi padi ke beras }}$

dimana:

KLPR = kebutuhan lahan pertanian $(\mathrm{Ha})$ 


$$
\begin{aligned}
\mathrm{KFM}= & \text { kebutuhan fisik minimum } \\
& (\mathrm{kg} / \mathrm{kapita} / \mathrm{tahun}) \\
\operatorname{Pr} & =\text { produktivitas lahan }(\mathrm{kg} / \mathrm{Ha})
\end{aligned}
$$

Berdasarkan data Badan Pusat Statistik tahun 2018, angka konversi gabah kering giling (GKG) menjadi beras yang digunakan adalah $64,02 \%$. Angka tersebut merupakan produksi beras rata-rata/ha dikonversikan dari padi ke beras. Jumlah penduduk optimal adalah banyaknya jiwa yang dapat didukung oleh lahan pertanian yang ada.

IPO $=\sigma \times$ Jumlah Penduduk

dimana:

JPO = jumlah penduduk optimal

$\sigma \quad=$ tingkat daya dukung lahan pertanian

\subsection{Neraca Air}

Berdasarkan SNI 6728.1-2015 neraca sumber daya air adalah informasi tentang imbangan potensi, ketersediaan dan penggunaan atau kebutuhan sumber daya air pada kurun waktu tertentu [7]. Neraca sumber daya air spasial dapat berfungsi sebagai salah satu informasi, kapan dan di wilayah mana terjadi defisit air.

1. Ketersediaan air

Ketersediaan air merupakan jumlah air yang tersedia pada sumber air. Ketersediaan air dapat berupa infrastruktur alami maupun buatan, seperti SPAM, embung, sumur bor dan waduk

2. Kebutuhan air

Kebutuhan air merupakan perkiraan jumlah air yang diperlukan untuk memenuhi hajat hidup kumpulan manusia, hewan, tumbuhan, maupun keperluan untuk proses produksi industri dan pembangkit listrik, serta untuk pemeliharaan lingkungan, yang jumlahnya dapat dihitung berdasarkan pemanfaatan air yang sudah ada, serta proyeksi sesuai dengan laju pertumbuhan para pengguna airnya.

3. Potensi air

Potensi air merupakan debit andalan. Debit andalan adalah debit minimal yang sudah ditentukan yang dapat dipakai untuk memenuhi kebutuhan air. Perhitungan ini menggunakan cara analisis water balance dari Dr. F.J Mock berdasarkan data curah hujan bulanan, jumlah hari hujan, evapotranspirasi dan karakteristik hidrologi daerah pengaliran. Evapotranspirasi dihitung menggunakan metode Penmann.

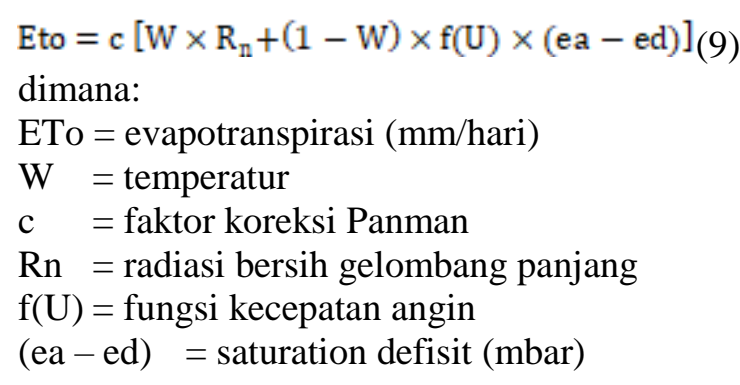

\section{METODE PENELITIAN}

\subsection{Lokasi Penelitian}

Lokasi penelitian ini terletak di Kabupaten Malaka, Provinsi Nusa Tenggara Timur. Kabupaten Malaka seluruhnya merupakan daratan dengan luas wilayah $1.160,63 \mathrm{Km}^{2}$. Secara astronomis terletak pada $124^{\circ} 88^{\prime} 25^{\prime}$ "Bujur Timur dan $9^{\circ} 10^{\prime} 26^{\prime}$ " Lintang Selatan [8]. Berdasarkan posisi geografisnya, Kabupaten Malaka memiliki batas-batas:

1. Utara - Kabupaten Belu

2. Selatan - Laut Timor

3. Timur - Negara Timor Leste

4. Barat-Kabupaten TTU dan TTS

Secara administratif kabupaten ini memiliki 12 kecamatan yang terdiri dari Kecamatan Wewiku, Malaka Barat, Weliman, Rinhat, Io Kufeu, Sasita Mean, Malaka Tengah, Botin Leobele, Laen Manen, Malaka Timur, Kecamatan Kobalima dan Kobalima Timur.

Secara geopolitik Kabupaten Malaka memiliki posisi strategis karena berbatasan langsung dengan Negara Republik Demokratik Timor Leste (RDTL). Kabupaten Malaka berbatasan darat atau langsung dengan Negara Timor Leste dan berbatasan laut dengan Negara Australia.

Tabel 1. Jumlah penduduk Kabupaten Malaka

\begin{tabular}{|c|c|}
\hline Tahun & Jumlah Penduduk \\
\hline 2010 & 165863 \\
\hline 2011 & 166438 \\
\hline 2012 & 168894 \\
\hline 2013 & 171079 \\
\hline 2014 & 174668 \\
\hline 2015 & 177892 \\
\hline 2016 & 181404 \\
\hline
\end{tabular}




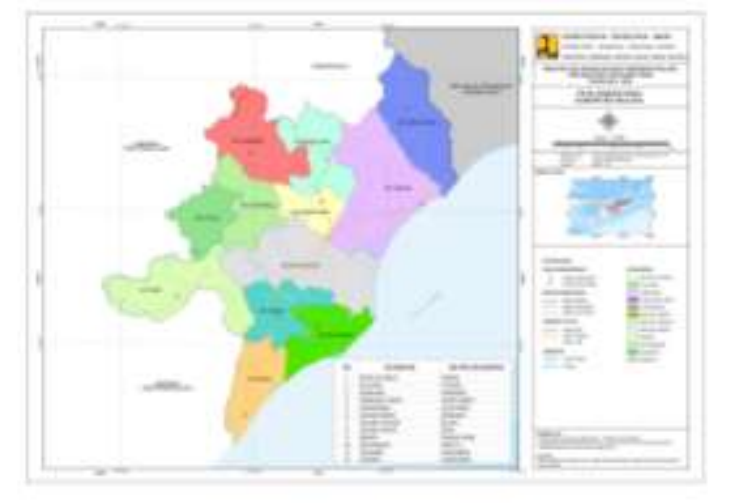

Gambar 1. Peta administrasi Kab. Malaka

\subsection{Bagan Alir Penelitian}

Bagan alir penelitian ditampilkan pada Gambar 1.

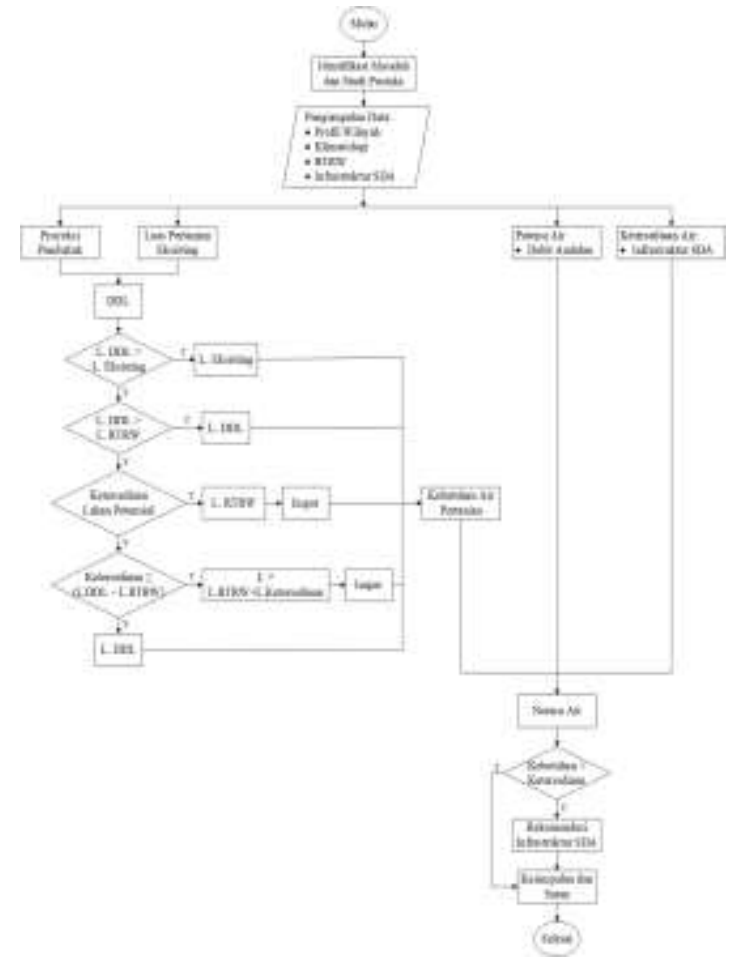

Gambar 2. Bagan alir penelitian

\section{HASIL DAN PEMBAHASAN}

\subsection{Proyeksi Penduduk}

Proyeksi penduduk dilakukan dalam jangka pendek yaitu tahun 2020-2024. Proyeksi penduduk dilakukan menggunakan data jumlah penduduk Kabupaten Malaka tahun 2010-2016 yang bersumber dari Badan Pusat Statistik.

Berdasarkan Tabel 2 didapatkan nilai koefisien korelasi tertinggi dan standar deviasi terendah pada metode aritmatika. Maka metode yang digunakan untuk memproyeksi jumlah penduduk Kabupaten Malaka menggunakan metode aritmatika.
Tabel 2. Hasil proyeksi jumlah penduduk

\begin{tabular}{|c|c|c|c|}
\hline Tahun & Aritmatika & Geometik & Eksponensial \\
\hline 2020 & 192.329 & 192.578 & 192.565 \\
\hline 2021 & 195.061 & 195.478 & 195.462 \\
\hline 2022 & 197.792 & 198.421 & 198.401 \\
\hline 2023 & 200.523 & 201.409 & 201.385 \\
\hline 2024 & 203.254 & 204.441 & 204.414 \\
\hline
\end{tabular}

Tabel 3. Nilai koefisien korelasi dan standar deviasi

\begin{tabular}{|c|c|c|}
\hline Metode & $\begin{array}{c}\text { Koef. } \\
\text { Korelasi }\end{array}$ & $\begin{array}{c}\text { Standar } \\
\text { Deviasi }\end{array}$ \\
\hline Aritmatik & 0,9985 & $14.063,70$ \\
\hline Geometrik & 0,9984 & $14.429,92$ \\
\hline Eksponensial & 0,9984 & $14.419,55$ \\
\hline
\end{tabular}

\subsection{Daya Dukung dan Kebutuhan Lahan}

Dalam penelitian ini, nilai kebutuhan fisik minimum (KFM) yang digunakan yaitu $154,10 \mathrm{~kg} / \mathrm{kapita} / \mathrm{tahun}$. Produktivitas padi di Kabupetan Malaka sebesar 3.909 kg/Ha. Berdasarkan data Badan Pusat Statistik tahun 2018, angka konversi gabah kering giling (GKG) menjadi beras yang digunakan adalah $64,02 \%$.

Tabel 4. Produktivitas lahan

\begin{tabular}{|c|c|c|c|c|}
\hline \multirow[t]{2}{*}{ Tahun } & \multirow[t]{2}{*}{$\begin{array}{l}\text { Jumlah } \\
\text { Penduduk }\end{array}$} & $\begin{array}{l}\text { Luas } \\
\text { Panen } \\
2016\end{array}$ & $\begin{array}{c}\text { Produksi } \\
\text { Beras }\end{array}$ & (Pr) \\
\hline & & $\mathrm{Ha}$ & ton & $\mathrm{kg} / \mathrm{Ha}$ \\
\hline 2016 & 181.404 & 7.484 & 29.254 & 3.909 \\
\hline 2020 & 192.329 & 7.484 & 29.254 & 3.909 \\
\hline 2021 & 195.061 & 7.484 & 29.254 & 3.909 \\
\hline 2022 & 197.792 & 7.484 & 29.254 & 3.909 \\
\hline 2023 & 200.523 & 7.484 & 29.254 & 3.909 \\
\hline 2024 & 203.254 & 7.484 & 29.254 & 3.909 \\
\hline
\end{tabular}

Tabel 5. Daya dukung lahan pertanian

\begin{tabular}{|c|c|c|c|c|}
\hline \multirow{2}{*}{ Tahun } & \multirow{2}{*}{$\mathrm{X}$} & $\mathrm{KFM}$ & \multirow{2}{*}{$\mathrm{K}$} & $\sigma$ \\
\cline { 3 - 4 } & & $\mathrm{kg} / \mathrm{org} / \mathrm{thn}$ & & \\
\hline 2016 & 0,041 & 154,10 & 0,039 & 1,046 \\
\hline 2020 & 0,039 & 154,10 & 0,039 & 0,987 \\
\hline 2021 & 0,038 & 154,10 & 0,039 & 0,973 \\
\hline 2022 & 0,038 & 154,10 & 0,039 & 0,960 \\
\hline 2023 & 0,037 & 154,10 & 0,039 & 0,947 \\
\hline 2024 & 0,037 & 154,10 & 0,039 & 0,934 \\
\hline
\end{tabular}

Tingkat daya dukung lahan pertanian Kabupaten Malaka dari tahun 2016-2024 
mengalami penurunan. Penurunan tingkat DDL ini disebabkan oleh peningkatan jumlah penduduk. Peningkatan jumlah penduduk berakibat pada peningkatan jumlah kebutuhan sehari-hari termasuk kebutuhan pangan, sehingga memerlukan perluasan lahan pertanian.

Nilai DDL tahun 2024 sebesar 0,934 yang berarti Kabupaten Malaka tidak mampu swasembada pangan, jumlah penduduk telah melampaui jumlah penduduk optimal. Oleh kerena itu diperlukan perluasan lahan pertanian yang mendukung pertumbuhan penduduk. Tabel 6 merupakan hasil perhitungan kebutuhan lahan pertanian berdasarkan proyeksi penduduk sampai tahun 2024 .

Tabel 6. Kebutuhan lahan pertanian

\begin{tabular}{|c|c|}
\hline \multirow{2}{*}{$\begin{array}{c}\text { Tahun } \\
\text { Proyeksi }\end{array}$} & KLPR \\
\cline { 2 - 2 } & $\mathrm{Ha}$ \\
\hline 2016 & 7.484 \\
\hline 2020 & 11.844 \\
\hline 2021 & 12.012 \\
\hline 2022 & 12.180 \\
\hline 2023 & 12.348 \\
\hline 2024 & 12.516 \\
\hline
\end{tabular}

Proyeksi penduduk tahun 2024 sebesar 203.254 orang, membutuhan luas lahan pertanian sebesar $12.516 \mathrm{Ha}$. Luas lahan eksisting pada tahun 2016 yaitu $7.484 \mathrm{Ha}$. Sehingga memerlukan perluasan lahan pertanian sebesar $5.032 \mathrm{Ha}$.

Luas pertanian lahan basah menurut RTRW 2014-2034 sebesar 13.968,72 Ha. Luas lahan pertanian tahun 2024 berada di bawah luas pertanian RTRW 2014-2034, maka hasil perhitungan luas pertanian tahun 2024 dapat digunakan untuk menghitung kebutuhan air pertanian.

Selanjutnya perlu dihitung jumlah penduduk optimal yang dapat didukung oleh hasil tanaman pangan dari luas lahan pertanian. Daya dukung lahan seimbang ditentukan apabila luas lahan pertanian yang ada pada suatu wilayah dapat memenuhi kebutuhan fisik minimum penduduknya. Jumlah penduduk optimal dapat dilihat pada Tabel 7.
Tabel 7. Jumlah penduduk optimal

\begin{tabular}{|c|c|c|}
\hline \multirow{2}{*}{ Tahun } & KLPR & $\begin{array}{c}\text { Jumlah } \\
\text { Penduduk }\end{array}$ \\
\hline & $\mathrm{Ha}$ & Optimal \\
\hline 2016 & 7.484 & 189.838 \\
\hline 2020 & 11.844 & 300.421 \\
\hline 2021 & 12.012 & 304.687 \\
\hline 2022 & 12.180 & 308.953 \\
\hline 2023 & 12.348 & 313.220 \\
\hline 2024 & 12.516 & 317.486 \\
\hline
\end{tabular}

Jumlah penduduk optimal yang dapat didukung oleh lahan pertanian di Kabupaten Malaka pada tahun 2024 sebanyak 317.486 jiwa.

\subsection{Kebutuhan Air Pertanian}

Berdasarkan Surat Edaran Menteri PUPR No. 07/SE/M/2018 tentang pedoman pembangunan embung kecil dan bangunan penampung air lainnya di desa, kebutuhan air untuk tanaman padi berkisar antara 1,0 - 1,5 liter/detik/ha [9].

Kebutuhan air untuk sawah irigasi ditetapkan 1 liter/detik/ha. Angka tersebut bila dikonversi dalam $\mathrm{mm}$ menjadi $1200 \mathrm{~mm} /$ tahun, jika sawah tersebut hanya sekali panen dalam satu tahun. Jika dua kali panen dalam satu tahun maka kebutuhan airnya menjadi 2400 $\mathrm{mm} /$ tahun. Jika pada lahan tersebut diselingi palawija (1 kali padi dan 1 kali palawija) maka kebutuhan airnya menjadi 2000 mm/tahun [10].

Tabel 8. Kebutuhan air pertanian

\begin{tabular}{|c|c|c|}
\hline Tahun & $\begin{array}{c}\text { Luas } \\
\text { Lahan } \\
\text { (ha) }\end{array}$ & $\begin{array}{c}\text { Kebutuhan } \\
\text { Air } \\
\left(\mathrm{m}^{3} / \text { detik }\right)\end{array}$ \\
\hline 2016 & 7.484 & 4,746 \\
\hline 2020 & 11.844 & 7,511 \\
\hline 2021 & 12.012 & 7,618 \\
\hline 2022 & 12.180 & 7,724 \\
\hline 2023 & 12.348 & 7,831 \\
\hline 2024 & 12.516 & 7,938 \\
\hline
\end{tabular}

\subsection{Debit Andalan}

Perhitungan evapotranspirasi potensial menggunakan rumus empiris dari Penmann yang memperhitungkan temperatur, radiasi matahari, kelembaban dan kecepatan angin sehingga hasilnya relatif lebih akurat. Data yang diperlukan untuk menganalisis evapotranspirasi potensial meluputi data 
klimatologi tahun 2008-2017.

Evapotranspirasi dibutuhkan dalam perhitungan debit andalan FJ Mock. Hasil perhitungan evapotranspirasi dapat dilihat pada tabel di bawah ini:

Tabel 9. Evapotranspirasi rata-rata $(\mathrm{mm} / \mathrm{bln})$

\begin{tabular}{|c|c|c|c|}
\hline Bulan & $\begin{array}{c}\text { Eto } \\
\text { Rata-rata }\end{array}$ & Bulan & $\begin{array}{c}\text { Eto } \\
\text { Rata-rata }\end{array}$ \\
\hline Jan & 146,502 & Jul & 118,919 \\
\hline Feb & 139,124 & Agu & 151,410 \\
\hline Mar & 158,791 & Sep & 178,749 \\
\hline Apr & 134,699 & Okt & 203,244 \\
\hline Mei & 125,704 & Nov & 192,577 \\
\hline Jun & 113,165 & Des & 160,726 \\
\hline
\end{tabular}

Perhitungan debit andalan FJ Mock dilakukan selama kurun waktu 10 tahun yaitu tahun 2007-2016. Kemudian melakukan perhitungan debit andalan menggunakan metode rangking dilakukan dengan data debit seri panjang, selanjutnya data tersebut disusun atau di rangking mulai dari urutan data debit yang terkecil ke yang terbesar. Setelah data diurutkan terlebih dahulu ditetapkan persentase debit andalan yang diharapkan. Keperluan irigasi biasanya ditetapkan debit tersedia $80 \%$ [11].

Tabel 10. Debit andalan terpilih

\begin{tabular}{|c|c|c|c|}
\hline Bulan & $\begin{array}{c}\text { Debit } \\
\text { Andalan } \\
\left(\mathrm{m}^{3} / \mathrm{dtk}\right)\end{array}$ & Bulan & $\begin{array}{c}\text { Debit } \\
\text { Andalan } \\
\left(\mathrm{m}^{3} / \mathrm{dtk}\right)\end{array}$ \\
\hline Jan & 23,989 & Jul & 2,496 \\
\hline Feb & 25,056 & Agu & 1,248 \\
\hline Mar & 28,012 & Sep & 0,645 \\
\hline Apr & 20,636 & Okt & 0,312 \\
\hline Mei & 9,985 & Nov & 0,161 \\
\hline Jun & 5,159 & Des & 27,895 \\
\hline
\end{tabular}

\subsection{Neraca Air}

Neraca air merupakan perbandingan antara potensi air, ketersediaan air terpasang, dan kebutuhan air di suatu wilayah untuk melihat kapasitas sumber daya airnya.

Berdasarkan analisis neraca air, terjadi gap (kesenjangan) antara kebutuhan air yang harus dilayani dibandingkan dengan ketersediaan infrastruktur yang ada. Hal ini menyebabkan perlunya dilakukan pembangunan infrastruktur untuk memenuhi kebutuhan air. Program pengembangan yang dapat dilakukan untuk mendukung ketahanan air yaitu konservasi DAS, pembuatan tampungan (waduk, embung, bendung, long storage) dan pengambilan air tanah tersistem.

Ketersediaan air di Kabupaten Malaka berupa insfrastruktur sumber daya air yang mendukung kegiatan pertanian berupa sumur bor JIAT dan embung. Terdapat 28 sumur bor dengan debit total $0,270 \mathrm{~m}^{3} /$ detik dan 27 embung dengan total kapasitas $702.878,35 \mathrm{~m}^{3}$ serta debit total $0,044 \mathrm{~m}^{3} /$ detik. Berikut merupakan hasil perhitungan neraca air pada Kabupaten Malaka.

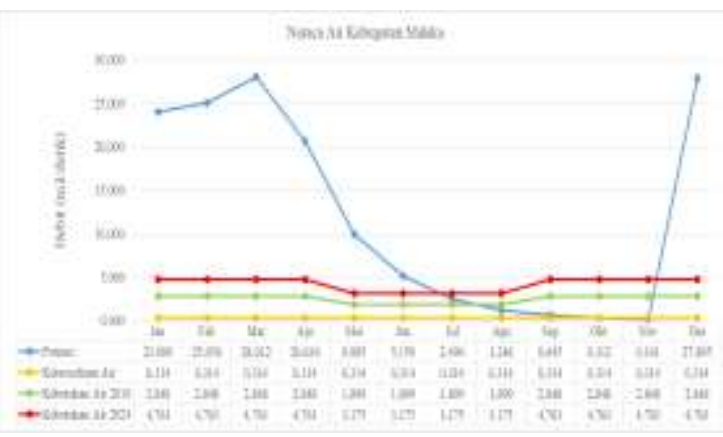

Gambar 2. Neraca air Kabupaten Malaka

Berdasarkan grafik tersebut ketersediaan infrastruktur bangunan air yang ada di Kabupaten Malaka belum dapat memenuhi kebutuhan air yang ada. Grafik potensi air pada bulan Juli-November berada di bawah garis kebutuhan, oleh karena itu pada bulan-bulan tersebut dibutuhkan tampungan untuk memenuhi kebutuhan air pertanian di Kabupaten Malaka.

\subsection{Analisis Tampungan}

Analisis volume efektif tampungan menggunakan metode Ripple. Metode kurva massa Ripple ini adalah plotting debit kumulatif tampungan dengan kemiringan kurva massa adalah nilai inflow pada waktu tertentu. Kemiringan kurva permintaan adalah kebutuhan air baku. Analisis dilakukan dengan melihat perbedaan antara garis yang bersinggungan dengan garis permintaan ditarik pada titik tertinggi dan titik terendah dari kurva massa. Nilai tersebut adalah kapasitas penyimpanan yang diperlukan.

Berdasarkan Gambar 3, kapasitas tampungan merupakan jarak vertikal antara garis massa debit dengan garis kebutuhan kumulatif pada titik ke 11 . 


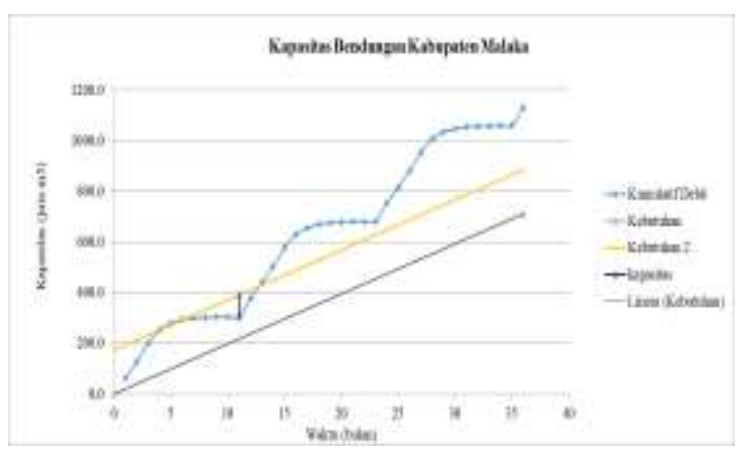

Gambar 3. Kurva ripple

Kapasitas = garis massa debit - garis kebutuhan kumulatif

Kapasitas $=391,278$ juta $\mathrm{m}^{3}-305,077$ juta $^{3}$ $=86,201$ juta $\mathrm{m}^{3}$

Garis kumulatif debit merupakan jumlah dari debit inflow yang masuk. Garis permintaan bersinggungan dengan lengkung inflow pada titik ke 6. Sehingga jarak dari titik ke 11 ke garis adalah 86,201 juta $\mathrm{m}^{3}$. Sehingga tampungan yang dibutuhkan untuk memenuhi kebutuhan air pertanian sebesar 86,201 juta $\mathrm{m}^{3}$. Penentuan lokasi dan tata letak bendungan harus memperhatikan beberapa hal diantaranya DAS yang ada di Kabupaten Malaka.

Tabel 11. Data DAS Kabupaten Malaka

\begin{tabular}{|c|c|c|}
\hline $\begin{array}{c}\text { Wilayah } \\
\text { Sungai }\end{array}$ & Nama DAS & Luas (Ha) \\
\hline Benanain & Mota Bahulu & $11.402,855$ \\
\hline Benanain & Alas & 904,020 \\
\hline Benanain & Alas Selatan & $1.521,828$ \\
\hline Benanain & Rainawe & $2.242,235$ \\
\hline Benanain & Lawalu & $20.296,867$ \\
\hline Benanain & Mota Babulu & $3.871,212$ \\
\hline Benanain & Halilamutu & 537,056 \\
\hline Benanain & Benanain & $60.753,103$ \\
\hline Benanain & Umalawain & $9.823,191$ \\
\hline Benanain & Toianas & 300,120 \\
\hline \multicolumn{2}{|c|}{ Jumlah } & $111.652,487$ \\
\hline
\end{tabular}

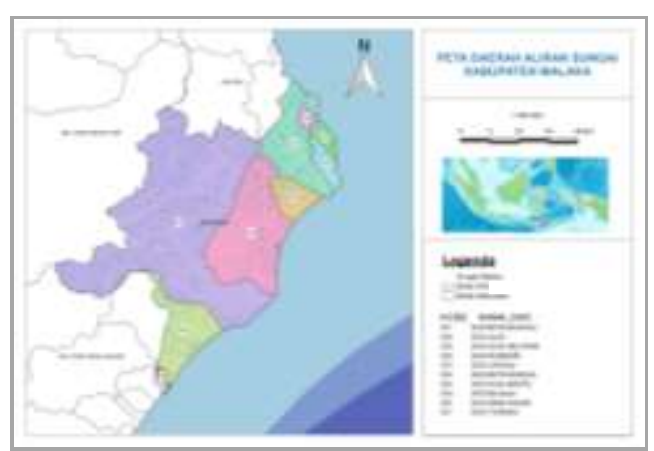

Gambar 4. Peta DAS Kabupaten Malaka

\section{KESIMPULAN DAN SARAN}

\subsection{Kesimpulan}

Berdasarkan hasil perhitungan yang telah dilakukan pada bab sebelumnya, maka dapat disumpulkan sebagai berikut:

1. Daya dukung lahan pertanian di Kabupaten Malaka tahun 2020-2024 sebesar $\sigma<1$, yang artinya wilayah tersebut tidak mampu swasembada pangan, penduduk melampaui batas optimal (over populated). Hal tersebut terjadi karena peningkatan jumlah penduduk. Peningkatan jumlah penduduk berakibat pada peningkatan kebutuhan pangan sehingga memerlukan perluasan lahan pertanian.

2. Proyeksi penduduk tahun 2024 sebesar 203.254 orang, untuk mencapai swasembada pangan maka membutuhkan luas lahan pertanian sebesar $12.516 \mathrm{Ha}$. Luas lahan eksisting pada tahun 2016 yaitu $7.484 \mathrm{Ha}$, sehingga memerlukan perluasan lahan pertanian sebesar 5,032 Ha. Luas pertanian lahan basah menurut RTRW 2014-2034 sebesar 13.968,72 Ha. Maka hasil perhitungan luas pertanian tahun 2024 dapat digunakan untuk menghitung kebutuhan air pertanian.

3. Berdasarkan grafik neraca air ketersediaan infrastruktur bangunan air yang ada di Kabupaten Malaka belum dapat memenuhi kebutuhan air yang ada. Grafik potensi air pada bulan Juli-November berada di bawah garis kebutuhan, oleh karena itu pada bulan-bulan tersebut dibutuhkan tampungan untuk memenuhi kebutuhan air pertanian di Kabupaten Malaka.

4. Analisis tampungan menggunakan metode Ripple menghasilkan volume tampungan yang dibutuhkan untuk memenuhi kebutuhan air pertanian sebesar 86,201 juta $\mathrm{m}^{3}$.

\subsection{Saran}

Setelah melalukan penelitian di atas, dapat dikemukakan beberapa saran sebagai berikut:

1. Dalam hal perijinan alih fungsi lahan harus benar-benar dilihat peruntukannya sehingga lahan pertanian yang ada di Kabupaten Malaka masih bisa mendukung dan mensuplai pangan bagi penduduknya dan melakukan ekspor ke negara tetangga. 
2. Perlu dilakukan penelitian lebih lanjut untuk menentukan lokasi bendungan dan perencanaan jaringan irigasi.

\section{DAFTAR PUSTAKA}

[1] The Economist Intelligence Unit (EIU), Global Food Security Index, Diakses dari http://foodsecurityindex.eiu.com/, 2018.

[2] Sulaiman, Andi Arman, dkk., Membangun Lumbung Pangan di Perbatasan (Sinergitas Merintis Ekspor Pangan di Wilayah Perbatasan NKRI, Jakarta: Kementerian Pertanian RI, 2017.

[3] UU No 18 Tahun 2012 Tentang Pangan.

[4] Anonim, Pilar Ketahanan Pangan, Diakses dari http://www.bulog.co.id//ketahananpangan_pilar .php, 2014.

[5] BPS (Badan Pusat Statistik), Pedoman Perhitungan Proyeksi Penduduk dan Angkatan Kerja, Jakarta: Badan Pusat Statistik, 2010.

[6] Kuncoro, Rama Dwi Setiyo, Analisis Daya Dukung dan Kebutuhan Lahan Pertanian di
Kabupaten Madiun Tahun 2032, Prosiding Seminar Nasional Geografi UMS., Surakarta, 2017 : 370-379.

[7] SNI 6728.1-2015 Penyusunan Neraca Spasial Sumber Daya Alam-Bagian 1: Sumber Daya Air

[8] BPS (Badan Pusat Statistik), Kabupaten Malaka dalam Angka, Jakarta: Badan Pusat Statistik, 2017.

[9] Surat Edaran Menteri PUPR No. 07/SE/M/2018 Tentang Pedoman Pembangunan Embung Kecil Dan Bangunan Penampung Air Lainnya Di Desa.

[10] Purnama, Ig. L. Setyawan, dkk., Analisis Neraca Air di DAS Kupang dan Sengkarang. Yogyakarta: Percetakan Pohon Cahaya, 2012.

[11] Hadisusanto, Nugroho, Aplikasi Hidrologi. Malang: Jogja Mediautama, 2010. 